\title{
Climate Change Impacts on Livestock Production Systems: A Review
}

\author{
Angie R. Poliquit \\ Accelerated S\&T Human Resource Development Program-National Science \\ Consortium Office, College of Agriculture and Food Science, Visayas State \\ University, Baybay City, Leyte 6521-A, Philippines
}

\begin{abstract}
The socio-economic contribution of livestock production to global livelihood and food security offsets its negative effects on the environment through greenhouse gas (GHG) emission. Livestocks are emitters of GHGs, carbon dioxide $\left(\mathrm{CO}_{2}\right)$ from land conversion and deforestation, nitrous oxide $\left(\mathrm{N}_{2} \mathrm{O}\right)$ from manure and slurry, and methane $\left(\mathrm{CH}_{4}\right)$ from animal digestion which significantly contribute to climate change. Climate change has both direct and indirect impacts on animal farming. Thus, the main concern nowadays is toward the development of programs for adaptation and mitigation of GHG emissions. This review provides knowledge about climate change impacts on livestock production systems with the identification of strategies for livestock adaptation to climate change and mitigation of GHG emissions.
\end{abstract}

Keywords: climate change, livestock, greenhouse gas, emission, enteric fermentation, adaptation, mitigation

Correspondence : A.R. Poliquit Address: Accelerated S\&T Human Resource Development ProgramNational Science Consortium Office, College of Agriculture and Food Science Visayas State University, Baybay City, Leyte6521-A, Philippines E-mail: angiepoliquit@ymail.com

DOI: $10.32945 / a t r 3628.2014$ 
Climate Change Impacts on Livestock Production Systems

\section{INTRODUCTION}

In the 2013 Maplecroft Climate Change Vulnerability Index (WFP, 2013), the Philippines ranked as the second most vulnerable country to climate change (Figure 1). Climate change is expected to have a strong impact on cities with changing weather patterns and increased intensity of weather events. Climate change refers to the changes in our climate system over a period of time (Capili et al., 2005). It is associated with modifications in global temperature, precipitation pattern, soil moisture, and sea level (PCARRD, 2009; Aydinalp and Cresser, 2008). Significant evidence of increased global average air by $0.7^{\circ} \mathrm{C}$ and ocean temperatures, and rising global average sea level by $25 \mathrm{~cm}$ was reported by IFAD (2009). According to Aydinalp and Cresser (2008), climate change is caused primarily by the release of greenhouse gases (GHG) that accumulate in the atmosphere which result to global warming. Changes in our climate affect the planet's various dynamic processes which certainly have impacts on crop and livestock production, hydrologic balances, input supplies and other components of agricultural systems as well as on forestry and on natural resource management (Capili et al., 2005; Adams et al., 1998; PCARRD, 2009).

In terms of climate change, it is important to consider the agriculture sector because it both contributes to and is affected by the changing climate. Globally, GHG emissions in the entire agricultural sector consist of about 9\% carbon dioxide $\left(\mathrm{CO}_{2}\right), 35-45 \%$ methane $\left(\mathrm{CH}_{4}\right)$, and $45-55 \%$ nitrous oxide $\left(\mathrm{N}_{2} \mathrm{O}\right)$ as shown in Figure 2 (WRI, 2005; McMichael et al. 2007; IPCC, 2007). Carbon dioxide enters the atmosphere through burning of fossil fuels, solid waste, trees, and wood products. It is also a result of certain chemical reactions such as the manufacture of cement. Major source of carbon emissions is from deforestation due to agricultural expansion and land conversion. It is removed from the atmosphere or sequestered when it is absorbed by plants as part of the biological carbon cycle. Carbon dioxide is only a small component of emissions in animal agriculture. The largest share of GHG emissions is from $\mathrm{CH}_{4}$ and $\mathrm{N}_{2} \mathrm{O}$ which are potent greenhouse gases (UNEP GEAS, 2012). Methane is emitted during the production and transport of coal, natural gas, and oil. It also comes from other agricultural practices and the decomposition of organic waste. Most of the methane releases come from paddy fields (91\%), from animal husbandry (7\%) and from the burning of agricultural wastes (2\%) while agriculture-based $\mathrm{N}_{2} \mathrm{O}$ emissions are emitted during agricultural and industrial activities, as well as during combustion of fossil fuels and solid 
waste. Nitrous oxide is also obtained from nitrogen fertilizer usage, legume cropping, and animal waste (Aydinalp and Cresser, 2008).

Effects of climate change on agriculture will vary across the world. Determining how climate will affect agriculture is complex since varieties of effects are likely to occur. Livestock production is not excepted from the impact of climate change. Hounghton et al. (2001) concluded that direct effects from air temperature, humidity, wind speed and other climate factors influence animal performance: growth, milk production, wool production and reproduction. Approximately $20-30 \%$ of animal species are at risk of extinction if global average temperature exceeds $1.5-2.5^{\circ} \mathrm{C}$ (FAO, 2007). As a result of climate change, food production is projected to decrease because of high mortality, less productivity, and more competition for natural resources (IFAD, 2009).

Adaptation strategies to climate change of livestock are limited to the modification of the physical environment through housing management which involves minimizing the effects of heat stress and the use of commercial vaccines and supplements to build-up the immune system of animal breeds. There are no definite programs for climate adaptation through genetic development of less heat-sensitive breeds or strains and for better feeding and nutritional strategies (PCARRD, 2009). The present concern is the development of a program for sustainability and economic viability of livestock production systems, while mitigating the negative impacts of livestock on the environment.

\section{CONTRIBUTIONS OF LIVESTOCK TO CLIMATE CHANGE}

The livestock sector appears as one of the top two or three most significant contributors to the most serious environmental problems which include stresses such as deforestation, desertification, excretion of polluting nutrients, overuse of freshwater, inefficient use of energy, diverting food for use as feed, and emission of GHGs (Steinfeld et al., 2006; Janzen, 2011). As stated by Steinfeld et al. (2006) and McMichael et al. (2007), GHGs from livestock constitute nearly $80 \%$ of all agricultural emissions. Meat production accounts for $18-25 \%$ of the world's emissions for the entire food chain (WSPA, 2012).

There are three main sources of GHG emissions in the livestock production system: the enteric fermentation of animals, manure, and production of feed and forage (Dourmad et al., 2008). The World Society for the Protection of Animals (WSPA, 2012) reported that animal farming 


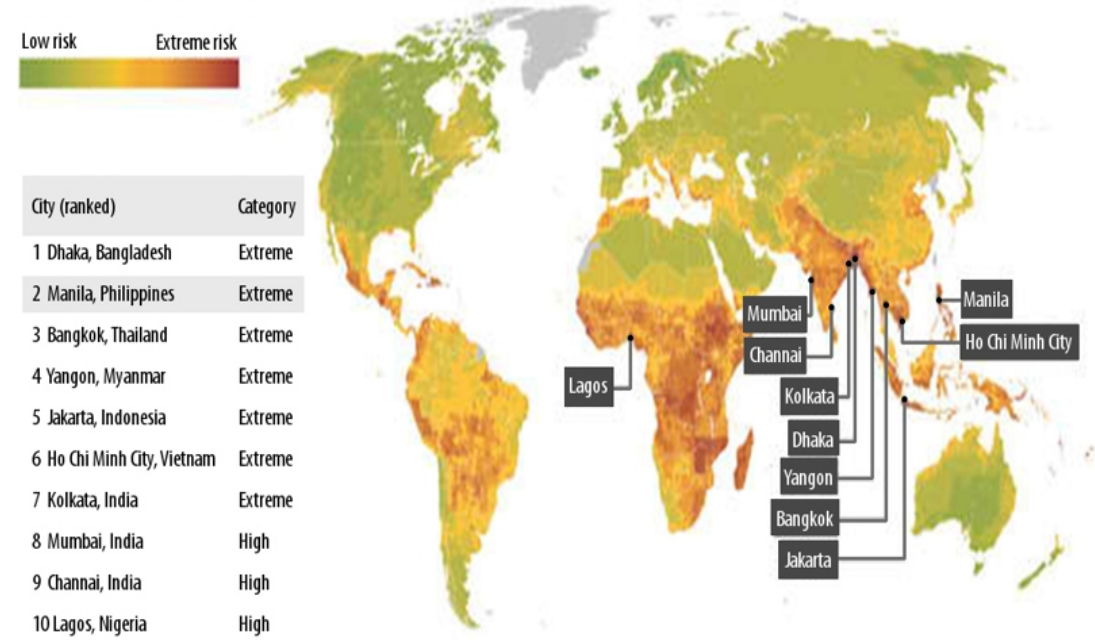

Figure 1. Maplecroft Climate Change Vulnerability Index 2013 (WFP, 2013).

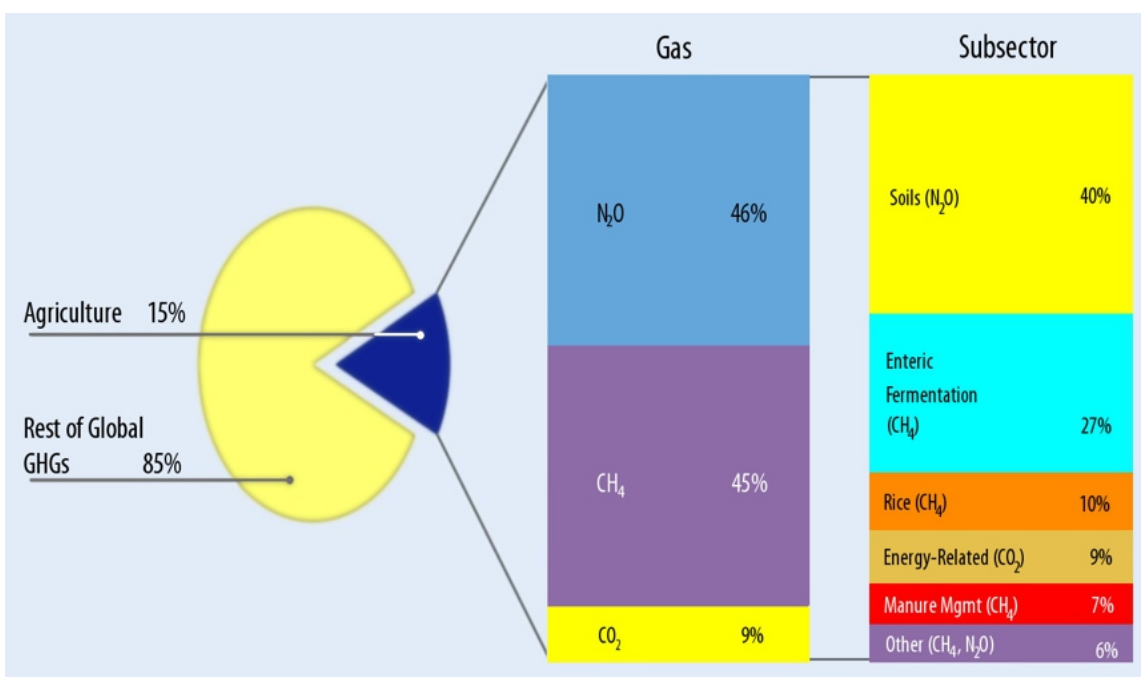

Figure 2. Contribution of agriculture sector to GHG emissions (WRI, 2005). 
contributes to $\mathrm{GHG}$ emissions through several routes. The most significant are $32 \% \mathrm{CO}_{2}$ from land use and its changes, 31\% $\mathrm{N}_{2} \mathrm{O}$ from manure and slurry and $25 \% \mathrm{CH}_{4}$ from animal digestion. The raising of livestock results in the emission of $\mathrm{CH}_{4}$ from enteric fermentation and $\mathrm{N}_{2} \mathrm{O}$ from excreted nitrogen, as well as from the chemical nitrogenous $(\mathrm{N})$ fertilizers used in the production of feeds (Lesschen et al., 2011; Herrero et al., 2011; O'Mara, 2011; Janzen, 2011; Reay et al., 2012). Enteric fermentation from ruminant production and manure management mostly from swine production are the greatest contributors of $\mathrm{CH}_{4}$ emissions (Monteny et al., 2006). The type of digestive system will also ascertain the amount of methane produced. For instance, ruminant animals with four compartment stomachs are designed for microbial fermentation of fibrous and high cellulose materials wherein one of its by-products is methane (Stevens and Hume, 1998). Methane is primarily produced in the rumen (87\%) and to a small extent (13\%) in the large intestine (Gibbs and Leng, 1993). Rumen methane is primarily emitted from the animal by eructation (Husted, 1994). Methane production from ruminants is illustrated in Figure 3. Production of methane depends on many factors especially the diet of the animal, its retention time, and microbial population in the rumen (Shete and Tomar, 2010). Monogastric animals with simple stomach and little microbial fermentation have less enteric methane production: methane is usually produced in the large intestines (Frédéric et al., 2007). Dairy and beef cattle are the largest emitters of enteric $\mathrm{CH}_{4}$, as they are the most numerous and are larger in body size relative to other species such as sheep and goats (UNEP GEAS, 2012; Del Grosso et al., 2011). However, the socio-economic contribution of livestock to the livelihood and food security outweighs its negative effect on the environment through GHG emissions (PCARRD, 2009).

There is a variety of factors affecting $\mathrm{CH}_{4}$ production in ruminant animals: the physical and chemical characteristics of the feed, the feeding level and schedule, the use of feed additives to promote production efficiency, and the activity and health of the animal (EPA, 2011). It has also been suggested that there may be genetic factors that affect $\mathrm{CH}_{4}$ production. Of all the factors, feed characteristics and feed rate have the most significant impacts. Feed, diet, and growth rate have effects on the amount and quality of manure that an animal excretes (Monteny, 2006). According to Del Grosso et al. (2008) higher energy feeds result in manure with more volatile solids, which increases the substrates from which $\mathrm{CH}_{4}$ is produced. Depending on the species, this impact is somewhat offset 
Climate Change Impacts on Livestock Production Systems

because some higher energy feeds such as those that are fed to poultry are more digestible than lower quality forages fed to ruminant animals and therefore less waste is excreted. The energy content and quality of feed affect the amount of methane produced in enteric fermentation where lower quality feed and higher quantities of feed cause greater emissions (USAFGG, 2008). In general, the greater the energy content of the feed, the greater the potential for $\mathrm{CH}_{4}$ emissions (EPA, 2011). However, some higher energy feeds are more digestible than lower quality forages, which can result in less overall waste excreted from the animal. Poorer quality high fiber diets will likely result in greater $\mathrm{CH}_{4}$ emissions than higher quality diets that contain more protein (Del Grosso et al., 2011). Typically, $\mathrm{CH}_{4}$ is usually produced following the degradation of carbon components during digestion of feed and manure (Monteny et al., 2006). Feed intake is positively correlated to animal size, growth rate, and production. It varies among animal types as well as among different management practices for individual animal types. In general, lower feed quality and/or higher feed intakes lead to higher emissions.

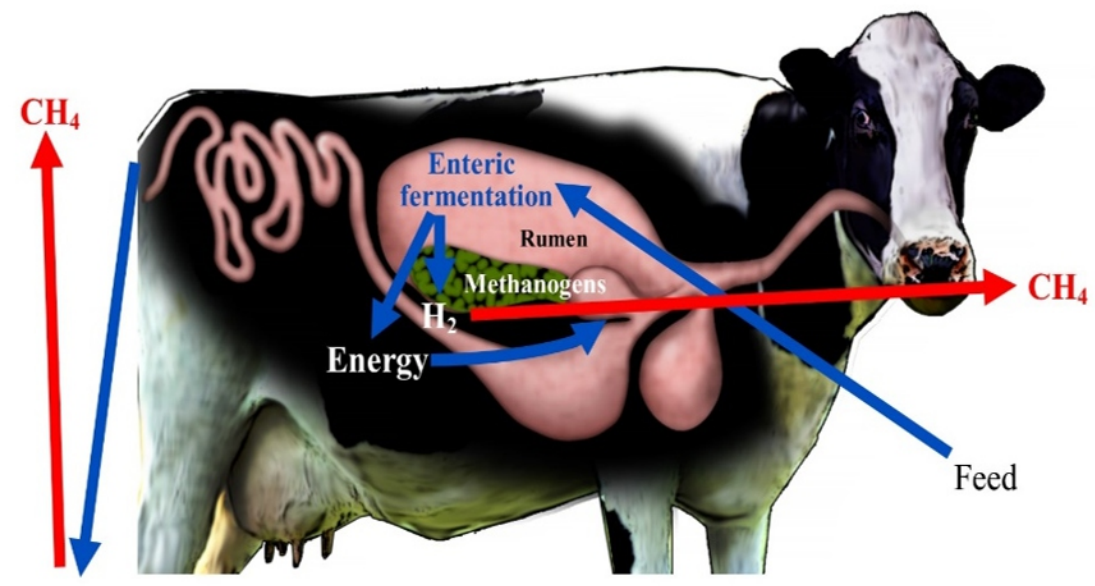

Manure

Figure 3. Methane production from ruminants (Shete and Tomar, 2010).

The livestock manure management can produce anthropogenic $\mathrm{CH}_{4}$ and $\mathrm{N}_{2} \mathrm{O}$ emissions. Direct $\mathrm{N}_{2} \mathrm{O}$ emissions are produced as part of the $\mathrm{N}$ cycle through nitrification and denitrification of the organic $\mathrm{N}$ in livestock dung and urine (Groffman et al., 2000). Indirect $\mathrm{N}_{2} \mathrm{O}$ emissions are produced as a result of the volatilization of $\mathrm{N}$ as ammonia $\left(\mathrm{NH}_{3}\right)$ and $\mathrm{NO}_{\mathrm{x}}$ and runoff and leaching of $\mathrm{N}$ during treatment, storage and transportation (Amon et al., 
2006). Direct $\mathrm{N}_{2} \mathrm{O}$ emissions are most likely to occur in dry manure handling systems that have aerobic conditions, but that also contain pockets of anaerobic conditions due to saturation (Groffman et al., 2000). Animal manure management is the second largest (second to cropping practices) $\mathrm{N}_{2} \mathrm{O}$ emitter in the agricultural sector.

The type of manure management system affects the amount of emissions and the type of gases that are emitted (EPA, 2011). Methane is produced by the anaerobic decomposition of manure (Palmer and Reeve, 1993). When livestock manure is stored or treated in systems that promote anaerobic conditions such as a liquid/slurry in lagoons, ponds, tanks, or pits, the decomposition of materials in the manure tends to produce more $\mathrm{CH}_{4}$ (EPA, 2011; USAFGG, 2008); but when manure is handled as a solid such as in stacks or drylots, or deposited on pasture, range, or paddock lands, it tends to decompose aerobically and produce little or no $\mathrm{CH}_{4}$ (Dunkley and Dunkley, 2013). Manure composition, which varies by animal diet, growth rate, and animal's digestive system, likewise affects the amount of $\mathrm{CH}_{4}$ produced (EPA, 2011). Also, ambient temperature, moisture, and manure storage or residency time affect the amount of $\mathrm{CH}_{4}$ produced because they influence the growth of the bacteria responsible for $\mathrm{CH}_{4}$ formation (Groffman et al., 2000; Amon et al., 2006; Del Grosso et al., 2008). For non-liquid-based manure systems, moist conditions can promote $\mathrm{CH}_{4}$ production. More than $90 \%$ of GHG emissions from managing untreated dairy slurry originated from $\mathrm{CH}_{4}$ produced during storage with 80-day retention (Amon et al., 2006). Amon et al. (2006) concluded that GHG abatement measures are most effective if they reduce $\mathrm{CH}_{4}$ emissions during storage. Covering the storage with straw increased $\mathrm{CH}_{4}$ and $\mathrm{N}_{2} \mathrm{O}$ emissions and resulted in the highest total GHG emissions. Petersen et al. (2005) demonstrated that oxidation can remove $\mathrm{CH}_{4}$ under practical storage conditions. Similarly, increases in GHG emissions following the application of straw covers to slurry storage were reported by Berg et al. (2006) in pig slurry and Cicek et al. (2004) in piggery lagoons. Possible reasons for the increases include sinking straw providing an additional carbon (C) source for methanogens, and that reduced surface mixing maintains optimum anaerobic conditions, both of which result in increased $\mathrm{CH}_{4}$ emissions. In addition, straw at the interface between $\mathrm{N}$ containing slurry and the atmosphere provides an environment for uncontrolled nitrification and denitrification and $\mathrm{N}_{2} \mathrm{O}$ emission (Cicek et al., 2004). If the separated solids are not composted with due attention to $\mathrm{C}: \mathrm{N}$, porosity and moisture content, $\mathrm{CH}_{4}$ emissions would remain high, and 
Climate Change Impacts on Livestock Production Systems

additional $\mathrm{N}_{2} \mathrm{O}$ emissions might be produced as a result of incomplete denitrification or nitrification under unfavorable conditions (Amon et al., 2006).

Harper (2000) stated that production and use of farmyard manure will largely affect $\mathrm{CH}_{4}$ emissions. For instance, cattle raised on pasture or range exhibit relatively high $\mathrm{N}_{2} \mathrm{O}$ emissions. In this system, manure and urine are deposited directly on the soil reducing $\mathrm{CH}_{4}$ emission. When cattle are raised under conditions where manure is collected and spread daily and there is no storage before it is spread onto the soil, there are low $\mathrm{CH}_{4}$ emissions and no $\mathrm{N}_{2} \mathrm{O}$ emissions (Dunkley and Dunkley, 2013). Emissions from swine and cattle reared in anaerobic lagoon management systems have variable $\mathrm{CH}_{4}$ emissions as it is mostly dependent on the duration of time the manure and slurry are stored in the lagoons (Harper, 2000). In this system, the waste can be stored between 30 to 200 days; the longer the storage time, the more likely the $\mathrm{CH}_{4}$ emissions will be high (Amon et al., 2006).

\section{IMPACTS OF CLIMATE CHANGE ON LIVESTOCK}

The livestock sector contributes drastically to the country's total agricultural output, but it is now threatened by both direct and indirect climate change impacts. The direct impacts include high environmental temperatures, excessive rainfall, flooding and droughts while the indirect impacts include low forage supply, high cost of feed grains, high cost of fossil fuel and emergence of new diseases (PCARRD, 2009). The economic impact of climate change on livestock is normally experienced as a decrease in productivity levels with low reproductive rates and reduced growth rates, as well as increased mortality rates in ruminant animals (Setshwaelo, 2001).

\section{A. Water}

Global water availability will be greatly affected by climate change and it may increase or decrease depending on the area (IFAD, 2009; SFA, 2009). This will not only affect the drinking water sources of livestock, but it will also influence livestock feed production systems and pasture yield (IFAD, 2009). Water use in the livestock sector includes water used at farm level for drinking, growing of feed crops, and other servicing and product processing roles (Thornton et al., 2009). Steinfeld et al. (2006) provided 
quantitative estimates of direct and indirect water use in the livestock sector.

Impacts of climate change on livestock's water demand are less uncertain, but the response of increased temperatures on water demand by livestock is well studied (Thornton et al., 2009). Thornton et al. (2009) reported that for Bos indicus, water intake increases from about $3 \mathrm{~kg} / \mathrm{kg}$ DM intake at $10^{\circ} \mathrm{C}$ ambient temperature, to $5 \mathrm{~kg}$ at $30^{\circ} \mathrm{C}$, and to about $10 \mathrm{~kg}$ at $35^{\circ} \mathrm{C}$ (NRC, 1981). For Bos taurus, intake at the same three temperatures is about 3, 8 and $14 \mathrm{~kg} / \mathrm{kg}$ DM intake. Some of this water intake comes from forage and forage water content may vary from close to $0-80 \%$, depending on species and weather conditions.

\section{B. Feeds}

Climate change is expected to have various impacts on feed crops and grazing systems. Both grazing and stall-fed ruminants will suffer from inadequate feed supply due to the occurrence of either drought or excessive rainfall. Continuous rains, flooding, and typhoons will shorten grazing period, while prolonged drought will extend grazing activity of ruminants and deplete water supply for drinking and bathing of heatstressed animals (PCARRD, 2009). These scenarios will have reduced feed intake of animals, thus, low in performance and productivity. In addition, feed refusal increases with decreasing body weight at high ambient temperatures (Close, 1989; Quiniou etal., 2000).

Land use and systems changes. Large tract of agricultural land is needed for livestock grazing and feed crop production. With decreasing land area due to industrialization and urbanization and an increasing demand for animal products, animal production systems have shifted from extensive to intensive system (PCARRD, 2009). As climate changes and becomes more variable, niches for different plant species alter and this may change animal diets (IFAD, 2009).

Changes in the primary productivity of crops, forage and rangeland. The effects will depend greatly on location, system, and species (IFAD, 2009). Changes in herbage growth may vary according to changes in atmospheric $\mathrm{CO}_{2}$ concentrations and ambient temperature (Hopkins and Del Prado, 2007). For instance, in $\mathrm{C}_{4}$ species, a rise in temperature to $30-35^{\circ} \mathrm{C}$ may increase the productivity of crops, fodder, and pastures. In $\mathrm{C}_{3}$ plants, rising 
Climate Change Impacts on Livestock Production Systems

temperature has a similar effect with $\mathrm{C}_{4}$ plants but increases in $\mathrm{CO}_{2}$ levels will have a positive impact on the productivity of these crops (IFAD, 2009). For food-feed crops, harvest indexes will change, as well as the availability of energy that can be metabolized for dry-season feeding.

Changes in plant species composition. As temperature and $\mathrm{CO}_{2}$ levels change, optimal growth for different plant species also change. In addition, species alter their competition dynamics and the composition of mixed grasslands changes such as modifications in the ratio of grasses to legumes (Hopkins and Del Prado, 2007; IFAD, 2009). For example, higher $\mathrm{CO}_{2}$ levels will affect the proportion of browse species which are expected to expand as a result of increased growth and competition between each other. Legume species will also benefit from $\mathrm{CO}_{2}$ increases and in tropical grasslands the mix between legumes and grasses could be altered which will affect the kind of plants that will be consumed by livestock (IFAD, 2009).

Quality of plant material. Rising temperatures cause an increase in lignification of plant tissues, thereby, reducing the digestibility and the degradation rates of plant species. The resultant reduction in livestock production may have an effect on global food security. Interactions between primary productivity and quality of grasslands will require alterations in the management of grazing systems to attain production objectives (IFAD, 2009). Disruption and frequent changes in the feeding regime of animals brought about by shortage in feed supply and poor quality of feeds will result in low productivity or increase in the cost of prevention and control of the occurrence of nutritionally-related disease (PCARRD, 2009).

\section{Heat stress}

Temperatures exceeding the higher critical level compromise animal performance not only by changing the energy and nutrient metabolism, but also by upsetting the body homeostasis, with detrimental consequences both for immunocompetence and for product quality (Babinszky et al., 2011). Warming will alter heat exchange between animal and environment; feed intake, mortality, growth, reproduction, maintenance, and production are all affected, potentially (SCA, 1990; Thornton et al., 2009). Under a hot and humid environment, the behavioral 
and physiological cooling mechanisms of high-producing farm animals such as reduction in voluntary feed intake, seeking shade, sweating, hyperventilation, defecation, urination, and salivation may not be sufficient to dissipate body heat. As a result, they succumb to excess heat load resulting in thermal stress. High ambient temperature causes hyperthermia in the body which reduces the activity of the appetite center in the medulla oblongata, thus, higher temperature triggers the reduction of voluntary feed intake which causes lower meat and milk production, lower reproductive rate, poor growth performance, and poor health condition (PCARRD, 2009; Rowlinson, 2008). The cause of the lower efficiency of nutrient and energy utilization is partly the higher energy use of animals due to heat stress, and partly the altered electrolyte balance of body fluids that may impair the protein metabolism (Patience, 1990). To lower heat production, farm animals reduce their physical activity (Collin et al., 2001) and spend less time with eating (Brown-Brandl et al., 2001).

Several studies have demonstrated that heat stress may reduce disease resistance or immune responsiveness of domestic animals; but, it depends on several variables, such as species and breed, duration of the exposure, severity of stress, and the type of immune response considered. A moderate heat stress would probably not modify immunological parameters (Lacetera et al., 2002); severe heat stress, however, may cause immune suppression, such as lower number of circulating white blood cells (Heller et al., 1979) and a reduction in antibody production (Zulkifi et al., 2000). Due to the production potential oriented selection, intensive genotypes are usually more susceptible to any disease. It should also be noted that the increasing temperature provides better conditions for microorganisms and viruses. At the same time the use of pharmaceuticals such as antibiotics or other drugs in food-producing animals may impair product quality and/or may constitute a food safety hazard, and can finally lead to a loss of consumer confidence in the product.

Rötter and van de Geijn (1999) suggested that impacts of heat stress may be relatively minor for the more intensive livestock production systems where some control can be exercised over the exposure of animals to climate. The wide geographic distribution of livestock production is some evidence for its adaptability to different climates. Similarly, the impacts of increased frequencies of extreme heat stress on existing livestock breeds are not known. As well as the relationship between heat stress and physiological impacts. Nevertheless, the tropics and subtropics contain a wealth of animal genetic resources that could be utilized in 
relation to heat-stress-related issues. There is considerable value in better understanding the match between livestock populations, breeds, and genes with the physical, biological, and economic landscape. This landscape livestock genomics approach should lead in the future to understanding the genetic basis of adaptation of the genotype to the environment (Seré et al., 2008). Over this longer term, ongoing genetic improvement through both natural and artificial selection should allow a certain degree of adaptation to gradual changes in climate (Thornton et al., 2009).

Limited local studies related to the vulnerability of livestock to high temperature and humidity conform to the findings of numerous studies done in foreign countries. In a study conducted by Vega et al. (2002) in swine, an analysis of three-year (2005 to 2008) monthly production data of 24 commercial farms with a total of 1,761 sow level revealed a third quarter swine reproductive syndrome, where values for farrowing interval and non-productive days were found to be worst during the months of July, August, and September. Among the possible reasons were that the animals were subjected to prolonged heat stress during the hot months of the second quarter (April-June) and continued until the hot and humid months of the third quarter (July-August) in time for parturition. Humidity has no direct negative impact on the animals, but when combined with high temperature will result to the occurrence of heat stress. Huynh et al. (2005) reported that ambient temperature strongly affects the pigs' physiological changes and performance, whereas relative humidity has a minor effect on heat stress in growing pigs; however, the combination of high temperature and high relative humidity lowered the average daily gain in pigs. Boars when subjected to $32-34^{\circ} \mathrm{C}$ for three consecutive days have increased number of morphologically abnormal sperm cells and lowered sperm motility. Thus, elevated temperature conditions are detrimental to spermatogenesis (Wettemann et al., 1979). Similar observations were reported by Tummuruk etal.(2002) in Thailand on the seasonal effects of high ambient temperature on reproductive performance of sows. Renaudeau et al. (2010) suggested that the apparent inefficiency of the sow mammary gland in hot conditions could be attributed to an increased rate of blood flow irrigating the skin capillaries in order to dissipate body heat and this in turn results in a lower blood flow to the mammary gland cells. Moreover, heat may also compromise the parameters of fertility: the quality of eggs and sperm deteriorates, embryo mortality between days 1 to 15 increases and maturity is delayed. In consequence, the number of piglets per sow may be less when sows are 
exposed to high ambient temperatures for longer periods of time. Studies with pair fed sows showed that the energy metabolism and hormonal status changed during heat stress (Prunier et al., 1997; Messias de Bragan et al., 1998). Studies have documented the decrease in feed intake of swine fatteners by almost $50 \%$ and feed conversion efficiency by $20 \%$ with increase in temperature from $15^{\circ} \mathrm{C}$ to $35^{\circ} \mathrm{C}$ (Myers and Bucklin, 2001). Recent publications highlight the fact that high temperatures not only impair growth but also change body composition and thus can impair the nutritive value and quality of pork. Prolonged heat stress $\left(30-33^{\circ} \mathrm{C}\right)$ reduces the rate of protein deposition in growing and finishing pigs (Kerr et al., 2003; Le Bellego et al., 2002). Heat stress has also detrimental effects on the reproduction of buffaloes, although buffaloes are well adapted morphologically and anatomically to hot and humid climate (Tailor and Nagda, 2005). Upadhyay et al. (2007) stated that thermal stress on Indian livestock particularly cattle and buffaloes has been reported to decrease estrus expression and conception rate. Maurya (2010) concluded that the length of service period and dry period of all dairy animals was increased from normal during drought. Furthermore, experimental studies were conducted by Mandal et al. (2002) on the effects of season and climate on production, performance, and other physiological parameters of dairy animals. The studies revealed that milk yield of crossbred cows in India are negatively correlated with temperature-humidity index. The lower feed intake and higher water consumption during heat stress result in a modified fermentation and volatile fatty acid production in the rumen since the high temperature may affect the functioning of rumen bacteria. The altered rumen fermentation influences not only milk yield but also milk composition by reducing its protein and fat content (Babinszky et al., 2011).

\section{Livestock diseases}

The disease outbreak was observed to be correlated with the mass movement of animals which in turn is dependent on the climatic factors. The impacts of climate changes on infectious diseases depend on the ecosystem affected, the type of land-use, disease specific transmission dynamics, and the susceptibility of the populations at risk (Patz et al., 2005a; Thornton et al., 2009). Changes in host-pathogen interactions result in an increased incidence of emerging diseases and disease epidemics (SFA, 2009). Climate change will affect not only those diseases 
Climate Change Impacts on Livestock Production Systems

that have high sensitivity to ecological change, but also significant health risks associated with flooding (Thornton et al., 2009).

Effects on pathogens. Higher ambient temperatures may increase the development rate of pathogens or parasites that spend some of their life cycle outside their animal host, which may lead to larger populations (Harvell et al., 2002). Other pathogens are sensitive to high temperatures and their survival may decrease with climate warming. Similarly, those pathogens and parasites that are sensitive to moist or dry conditions may be affected by changes in precipitation, soil moisture, and the frequency of flooding. Changes to winds could also affect the spread of certain pathogens and vectors (Thornton et al., 2009).

Effects on hosts. Baylis and Githeko (2006) mentioned that mammalian cellular immunity can be suppressed following heightened exposure to ultraviolet $\mathrm{B}$ radiation which is an expected outcome of stratospheric ozone depletion. Therefore, GHG emissions that affect ozone could have an impact on certain animal diseases. A more important effect may be on genetic resistance to disease; and while animals often have evolved genetic resistance to diseases to which they are commonly exposed, they may be highly susceptible to new diseases (Thornton et al., 2009). Climate change may bring about substantial shifts in the distribution of disease, and severe disease outbreaks could occur in previously unexposed animal populations possibly with the breakdown of endemic stability (Thornton etal., 2009).

Effects on vectors. There may be several impacts of climate change on the vectors of disease such as flies, ticks, mosquitoes, and tsetse which are all important vectors of livestock disease in the tropics. Hot-humid weather conditions were found to aggravate the infestation of cattle ticks like: Boophilus microplus, Haemaphysalis bispinosa and Hyalomma anatolicum (Basu and Bandhyopadhyay, 2004). Changes in rainfall and temperature regimes may affect both the distribution and the abundance of disease vectors. It has also been shown that the ability of some insect vectors to become or remain infected with viruses varies with temperature (Wittmann and Baylis, 2000). The feeding frequency of arthropod vectors may also increase with rises in temperature. As many vectors must feed twice on suitable hosts before transmission is possible (to acquire and then to transmit the infection), warmer temperatures may increase the 
likelihood of successful disease transmission (Thornton et al., 2009). Vector-borne diseases could be affected through the expansion of vector populations into cooler areas or into more temperate zones. Likewise, the diseases could also be affected by the changes in rainfall pattern during wetter years, which could also lead to expanding vector populations and large-scale outbreaks of disease (IFAD, 2009).

Effects on epidemiology. Climate change may alter the rate of transmission between hosts not only by affecting the survival of the pathogen or parasite or intermediate vector but also by other means. Future patterns of international trade, local animal transportation, and farm size are factors that may be driven in part by climate change, and may affect disease transmission (Thornton et al., 2009).

Other indirect effects. Climate change may also affect the abundance and/or distribution of the competitors, predators, and parasites of vectors themselves, thus influencing disease patterns. It may also be that changes in ecosystems, driven by climate change and other drivers that affect landuse, could give rise to new mixtures of species, thereby exposing hosts to novel pathogens and vectors and causing the emergence of new diseases (WHO, 1996). In addition, Kovats et al. (2001) noted that there has been a tendency to oversimplify the mechanisms by which climate change may affect disease transmission. There are in general many factors operating, and considerably more work is needed on disease dynamics and how these may adapt to a changing climate (Thornton et al., 2009).

Climatic factors play important roles in the etiology of animal diseases, particularly those of respiratory in nature. Outbreak of water-borne, water-mediated, and vector-borne diseases is likely to increase morbidity and mortality of animals during extreme climatic events.

\section{E. Biodiversity}

In some places there will be acceleration in the loss of the genetic and cultural diversity already in agriculture as a result of globalization in varieties of domestic animals. A $2.5^{\circ} \mathrm{C}$ rise in global temperature would determine major losses: between 20 and $30 \%$ of all plant and animal species assessed could face a high risk of extinction (IFAD, 2009). Of the estimated 4000 breeds of ass, water buffalo, cattle, goat, horse, pig, and sheep recorded in the $20^{\text {th }}$ century, some $16 \%$ had become extinct by 2000 , 
Climate Change Impacts on Livestock Production Systems

and $12 \%$ of what was left was rare. The $2007 \mathrm{FAO}$ report on animal genetic resources indicates that $20 \%$ of reported breeds are now classified as at risk, and that almost one breed per month is becoming extinct (CGRFA, 2007). However, there is a considerable regional variation. Much of this genetic erosion is attributed to global livestock production practices and the increasing marginalization of traditional production systems and associated local breeds (Thornton et al., 2009).

The potential for widespread genetic devastation in the future as a result of inexorably rising temperatures is great. Ecosystems and species are very likely to show a wide range of vulnerabilities to climate change, depending on the imminence of exposure to ecosystem-specific, critical thresholds. There is no doubt that the livestock sector itself is a major driver in habitat and landscape change, and thus plays a significant role in biodiversity loss (Thornton et al., 2009). The complexity of ecosystems means that it is extremely difficult to assess the impacts of climate change on biodiversity. Local and rare breeds could be lost as a result of the impact of climate change and disease epidemics. Biodiversity loss has global health implications and many of the anticipated health risks driven by climate change will be attributable to a loss of genetic diversity (IFAD, 2009).

\section{F. Indirect impacts}

In addition to the direct impacts of changing climate on many aspects of livestock systems, there are various indirect impacts that can be expected to impinge on livestock keepers. One of the most significant of these is the impact on human health. As with livestock diseases, the changes wrought by climate change on infectious disease burdens may be extremely complex. Patz et al. (2005b) listed several diseases as high priority for their large global burden of disease and their high sensitivity to ecological change. (Thornton etal., 2009)

Another major indirect impact of climate change on livestock is fungal contamination (mycotoxins) of stored feed ingredients due to prolonged rainfall (PCARRD, 2009).

\section{ADAPTATION AND MITIGATION STRATEGIES TO CLIMATE CHANGE}

Livestock is more resistant to climate change than crops because of its mobility and accessibility to feed. They play an important role in both 
mitigation and adaptation. Mitigation measures include technical and management options to reduce GHG emissions from livestock, accompanied by the integration of livestock into broader environmental services (IFAD, 2009).

\section{A. Adaptation strategies}

Traditionally, livestock producers have adapted to various climatic changes by building on their in-depth knowledge of the environment. Sidahmed (2008) stated that through the expansion of human population, urbanization, environmental degradation and increased consumption of animal source foods, coping mechanisms have rendered ineffective. To increase adaptation in the livestock sector the following have been identified (FAO, 2008a; Thornton et al., 2008; Sidahmed, 2008):

Adjustments on livestock production. Modifying livestock practices include: diversification, intensification and/or combination of pasture management, crop and livestock production; changing land use and irrigation; altering the timing of operations; nature and ecosystem conservation; modification of stock routings and distances; and introduction of mixed livestock farming systems (Thornton et al., 2008).

Livestock breeding plans. Most of the local breeds of animals are already adapted to harsh living conditions. Adaptation strategies address not only the tolerance of livestock to heat, but also their ability to survive, grow, and reproduce in conditions of poor nutrition, parasites, and diseases (Hoffmann, 2008). Adaptation measures could include: identifying and strengthening local breeds that have adapted to local climatic stress and feed sources; and improving local genetics through crossbreeding with heat and disease tolerant breeds (FAO, 2008a; Sidahmed, 2008).

Institutional and policy changes. Removal or introduction of subsidies, insurance systems, income diversification practices and establishing livestock early warning systems like crisis-preparedness schemes could benefit adaptation efforts (Thornton et al., 2008; Sidahmed, 2008).

Science and technology development. Better understanding of the impacts of climate change on livestock, development of new animal breeds and genetic types, improving animal health and enhancing water and soil 
Climate Change Impacts on Livestock Production Systems

management would support adaptation measures in the long term (FAO, 2008a; Sidahmed, 2008).

Capacity building for livestock keepers. Improvement of livestock producers' capacity helps to understand and deal with climate change. In addition, trainings on agroecological technologies for fodder production and conservation improves animal feed supply and reduces malnutrition and mortality in herds (Thornton et al., 2008; Sidahmed, 2008).

Livestock management systems. Efficient and affordable adaptation technologies include (i) provision of shade and water to reduce heat stress by providing natural and low cost shade with increased roof height; (ii) reduction of livestock number wherein a lower number of more productive animals leads to more efficient production and lower GHG emissions (Batima, 2007); (iii) changes in herd composition through selection of large animals rather than small; and (iv) improved water resource management through the introduction of simple techniques for localized irrigation, accompanied by infrastructure to harvest and store rainwater.

Several reviews of different methods of environmental modifications to relive heat stress have been published (e.g. Bucklin et al., 1991; Hahn, 1989). The different methods of environmental modification include: shades, ventilation, combination of wetting, and ventilation. Shades, either natural or artificial, are the simplest method to reduce the impact of high solar radiation. Tree shades have proved to be more efficient (Hahn, 1985). When natural shade is unavailable, artificial structures may be constructed. Different aspects concerning design and orientation of shades have been published (Bucklin et al., 1991; Buffington et al., 1983; Hahn, 1989; Valtorta et al., 1997). In a study performed by Valtorta et al., (1996) on dairy cows, he found that protected animals presented lower afternoon rectal temperature and respiration rate, and yielded more milk and protein. The artificial shade structure did not differ from tree shades, in terms of the effects on animal well-being (Valtorta et al., 1997). Air moving according to air humidity and evaporative heat losses is an important factor in the relief of heat stress. Natural ventilation should be maximized by constructing open-sided housing (Bucklin et al., 1991). Forced ventilation, provided by fans, is a very effective method if properly designed. An effective way of cooling cattle is spray evaporative cooling with several methods available such as mist, fog, and sprinkling systems (Armstrong and Wiersma, 1986; Hahn, 1985; Schultz, 1988; Strickland et 
al., 1989; Turner et al., 1989). They discuss the effectiveness of these systems under confined production schemes. The single use of a sprinkling and fan system, for 30 minutes before milking, has proved to be useful to relive dairy cows' heat stress, in terms of efficiency to reduce the impact of heat waves under a grazing system (Valtorta et al., 2002).

\section{B. Mitigation of GHG emissions}

Unmitigated climate change will exceed natural and human systems capacity to adapt. It is essential to identify mitigation measures which are easy to implement and cost effective, to strengthen the capacity for climate change adaptation. Livestock production contributes directly to global climate change through the production of GHG emissions, and indirectly through the destruction of biodiversity, degradation of land, and water and air pollution. Indirect sources of GHGs from livestock are mainly attributable to changes in land use and deforestation to create pasture land. Mitigation of GHG emissions in the livestock sector can be achieved through various activities, including (FAO, 2008b):

Selection offaster growing animal breeds. Increasing feed efficiency and improving the digestibility of feed are potential ways to reduce GHG emissions and maximize production and gross efficiency, as is lowering the number of heads. All livestock practices such as genetics, nutrition, reproduction, health and dietary supplements, and proper feeding management could result in improved feed efficiency (IFAD, 2009).

Nutritional and management strategies. Successful methane emission reduction options depend on several factors including climate, economic, technical and material resources, existing manure management practices, regulatory requirements and the specific benefits of developing an energy resource, and a source of high quality fertilizer. Joblin (1999) and Martin et al. (2010) listed some strategies to reduce enteric methane emissions such as: direct inhibition of methanogenesis, lowering of the production of hydrogen during fermentation, and providing alternative pathways for use of hydrogen in the rumen.

Feed composition has some bearing on enteric fermentation and $\mathrm{CH}_{4}$ emission from the rumen (Dourmad et al., 2008). A higher proportion of concentrate in the diet results in the reduction of methane emission (Lovett et al., 2005). Methane production in the digestive system of the 
Climate Change Impacts on Livestock Production Systems

animal especially in ruminants can be reduced with the use of feed additives, antibiotics or vaccines (UNFCCC, 2008).

The amount of feed intake is related to the amount of waste product. Reducing the amount of feed required per animal has the potential to reduce the production of GHGs (Beauchemin and McGinn, 2008). Feed efficiency can be increased by developing breeds that are faster growing with improved hardiness, weight gain or milk production. Feed efficiency can also be increased by improving herd health through improved veterinary services, preventive health programmes, and improved water quality (SFA, 2009).

a. Type of carbohydrates. Cell wall carbohydrates fermentation produces more methane than soluble sugars. High grain diet leads to high rate of ruminal digestion and faster passage rate which favor higher propionic acid production and will also lower ruminal $\mathrm{pH}$ that inhibits the growth of methanogenic bacteria and protozoa (Shete and Tomar, 2010). However, for a drop in $\mathrm{CH}_{4}$ production to occur, the finishing diet needs to contain starch-based grain rather than high-fiber byproduct feeds and must comprise more than $90 \%$ of the diet (Beauchemin and McGinn, 2008).

b. Forage species and maturity. Methane emissions are lower from animals fed with legume forages compared with those fed with grasses (McCaughey et al., 1999; Benchaar et al., 2001), but this relationship is influenced by the maturity of the forage (Chaves et al., 2006). Increase methane production in ruminants was observed with maturity of forage fed and methane emission from the ruminal fermentation of legume forages was generally lower than those from grasses (Shete and Tomar, 2010). The lower $\mathrm{CH}_{4}$ observed with legumes is attributed to lower fiber content and faster rate of passage of feed through the rumen (Beauchemin and McGinn, 2008).

c. Feeding frequencies. Low feeding frequencies cause an increase in propionic acid production and reduce acetic acid. Also, there is a high fluctuation in the ruminal $\mathrm{pH}$ which inhibits methanogens and reduces methane production (Shete and Tomar, 2010).

d. Forage processing. Grinding or pelleting of forages improves the utilization of ruminants which lessens methane production due to lowered 
fiber digestibility, decreased available organic matter in the rumen, and faster passage rate (Shete and Tomar, 2010).

e. Forage preservation. Methane production is lower when forages are ensiled due to extensive fermentation that occurs during silage-making. Rumen fermentation of silage is characterized by higher molar proportion of butyrate and lower proportion of acetate (Shete and Tomar, 2010).

Better waste management. Improving the management of animal waste products through different mechanisms is important. The level of GHG emissions from manure depends on the temperature and duration of storage. Long-term storage at high temperatures results in higher GHG emissions. In the case of ruminants, pasture grazing is an efficient way to reduce $\mathrm{CH}_{4}$ emission from manure because no storage is necessary (IFAD, 2009). Methane mitigation options involve the capture of methane by covered manure storage facilities, such as biogas collectors, which can be flared or used to provide a source of energy for electric generators, heating or lighting which can offset $\mathrm{CO}_{2}$ emissions from fossil fuels (SFA, 2009).

Treatments involving anaerobic digestion, aeration, and solids separation were effective at reducing GHG emissions compared with untreated slurry (Amon et al., 2006). Separated solids must undergo true aerobic composting to mitigate GHGs. Minimal intervention composting or stockpiling solids without turning is a simple and effective, although slow, means of reducing volume and volatile solids. Lopez-Real and Baptista (1996) found that forced aeration and turned windrows were effective composting procedures and substantially reduced $\mathrm{CH}_{4}$ emissions compared with static stockpiles.

Hegarty's (2001) recommendation was to minimize the volume of manure produced by ensuring that the energy requirements of the animals are met from the highest digestibility feed available and are fed only at levels required for the desired animal performance. The less the amount of volatile solids and $\mathrm{N}$ to be decomposed, the less will be the emissions of $\mathrm{CH}_{4}$ and $\mathrm{N}_{2} \mathrm{O}$.

Grazing management. Increased use of pasture to provide feed and good management through rotational grazing are potentially the most cost effective ways to reduce and offset GHG emissions (SFA, 2009). Grazing animals also help reduce emissions attributable to manure storage. Introducing grass species and legumes into pasture area can enhance 
Climate Change Impacts on Livestock Production Systems

carbon storage in soils (IFAD, 2009). Improved grazing management also generally improves the profitability of production.

Lowering livestock production and consumption. Lowering the consumption of meat and milk is a short-term response to GHG mitigation (IFAD, 2009).

Reducing deforestation. Deforestation for new pasture or land for feed crop production releases more $\mathrm{CO}_{2}$ than any other livestock-related activity. Intensification of pasture management and feed production can reduce the land requirements per unit of animal product produced, thus, shortening land-use expansion (SFA, 2009).

Improve animal productivity. When animal productivity is improved through nutrition, management, and reproduction or genetics, methane production per unit of milk or meat is reduced because the number of animals required to produce the same amount of milk or meat is lessened. In general, the approach of reducing $\mathrm{CH}_{4}$ emissions by increasing animal productivity works best when a supply management system limits the total amount of product produced (Beauchemin and McGinn, 2008). Different production enhancing agents like bovine somatotropin (bST) are also available but is not recommended for use due to health risks (Shete and Tomar, 2010).

Manipulation of Rumen Fermentation. Zijderveld (2011) accounted some of the feeding management strategies to mitigate GHG emissions which include: improving the nutritive value of poor quality roughages by urea treatment or molasses spraying; usage of mineral blocks; application of ionophores, probiotics and prebiotics to improve rumen fermentation; utilization of secondary plant metabolites such as tannins and phenolic compounds to reduce methanogenesis in ruminants; and biotechnological interventions to reduce methanogenic archia in rumen.

a. Addition of fats. Supplementing diets with fats and oils lowers enteric $\mathrm{CH}_{4}$ emissions. Dietary fat is not fermented in the rumen and, consequently, less hydrogen per unit of feed is produced when higher fat levels are included in the diets for ruminants. Addition of fats in feed increase the energy density of diet thereby causing lower intake of fibrous feed resulting in low methane production (Shete and Tomar, 2010). Fats 
also lower the number of protozoa in the rumen, many of which are physically associated with the methanogens. Some fats may depress $\mathrm{CH}_{4}$ emissions because they are toxic to the rumen methanogens. Fats rich in unsaturated fatty acids also reduce $\mathrm{CH}_{4}$ formation in the rumen because they compete with methanogens for $\mathrm{H}_{2}$ (Beauchemin and McGinn, 2008). With each $1 \%$ fat that is added to the diet, $\mathrm{CH}_{4}$ production is reduced by about 5.6\% (Beauchemin et al., 2008). The response also depends on the fat source, the form in which the fat is administered, and the type of diet (Shete and Tomar, 2010).

Increasing the dietary fat content has therefore been proposed as a promising strategy to reduce methane emissions from ruminants (Eugene et al., 2008; Martin et al., 2010). Moreover, individual fatty acids have been considered to have specific anti-methanogenic properties, and methane production could be further reduced by using these specific fatty acids (Czerkawski et al., 1966; Ajisaka et al., 2002; Machmuller, 2006). Addition of dietary fats and oils has been shown to lower methane emissions from ruminants in numerous studies (Machmuller et al., 2003; Jordan et al., 2006; Martin et al., 2008). Oils containing high concentrations of longchain fatty acids (LCFA), such as oilseeds and animal fats, have reduced $\mathrm{CH}_{4}$ emissions (Beauchemin et al., 2008), and are reported to have a greater effect compared with MCFA (Machmüller, 2006). This is partially attributed to reduced fiber degradation and decreased dry matter intake (DMI) when animals are supplemented with LCFA (Beauchemin et al., 2008). Long chain fatty acids reduce $\mathrm{CH}_{4}$ production by consuming $\mathrm{H}_{2}$ as they undergo hydrogenation in the rumen, which differs from the proposed antimicrobial mechanism of MCFA (Machmüller, 2006).

b. Propionate precursors. Increasing the presence of propionate precursors such as pyruvate, oxaloacetate, malate, fumarate, and succinate result to more hydrogen to be used for propionate production. The dicarboxilic acids, fumarate and malate are potential hydrogen acceptors that reduce methane production in ruminants (Shete and Tomar, 2010).

c. Defaunation. Methanogenic bacteria are generally attached to the exterior surface of rumen ciliate protozoa in the rumen and therefore, removal of protozoa from the rumen through defaunation has been associated with reduction in methane production (Shete and Tomar, 2010). 
Climate Change Impacts on Livestock Production Systems

d. Stimulation of acetogens. Rechanneling substrates for methane production to another product is another way to decrease methane production. The production of acetic acid by the reduction of carbon dioxide with hydrogen of some acetogenic bacteria lowers methane production when added to rumen fluid in vitro. Even if a stable population of acetogens could not be established in the rumen, it is possible to achieve the same metabolic activity using the acetogens as a daily feed additive (Shete and Tomar, 2010).

e. Ionophores. Ionophores are known to inhibit growth of methanogens leading to the reduction of methane production. Monensin, lasalocid, and salinomycin are some examples of ionophores (Shete and Tomar, 2010).

Monensin, a commonly used ionophore in ruminant nutrition, is widely used for the control of bloat in cattle, and has production benefits for dairy cows in terms of milk production and feed conversion efficiency (McGuffey et al., 2001; Ruiz et al., 2001; Ipharraguerre and Clark, 2003). It has antimicrobial properties that affect gram-positive microbes, such as protozoa, which are associated with a high proportion of $\mathrm{H}_{2}$ production and can indirectly account for up to $20 \%$ of methanogenesis in the rumen (Guan et al., 2006). It shifts the volatile fatty acid (VFA) pattern in the rumen towards propionate, thereby providing an alternative hydrogen sink. Decreases in $\mathrm{CH}_{4}$ production up to $10 \%$ are possible with monensin, depending upon the dose but the reduction of $\mathrm{CH}_{4}$ is not always sustained over time (Beauchemin and McGinn, 2008). The long-term persistency of monensin in methane mitigation is not clear, with studies demonstrating a persistent effect (Odongo et al., 2007), while another study showed the effect to be transient (Guan et al., 2006).

f. Secondary plant metabolites. Many plant extracts, for instance, tannins, saponins, and essential oils have been screened in vitro for their potential to directly inhibit methanogenesis as reviewed by Calsamiglia et al. (2007) and Garcia-Gonzalez et al. (2008). Plant secondary compounds are present in some legumes and herbs and have been found to lower $\mathrm{CH}_{4}$ yield. However, not all of these compounds appear effective at reducing $\mathrm{CH}_{4}$ yield and needs further research to elucidate the impact of dietary chemical composition, potential degradation rates, and digesta kinetics of fresh forages on ruminant $\mathrm{CH}_{4}$ emissions. The addition of lipids with 
antimicrobial activity to the animal diet may increase the energy density of the diet and improve animal production, while lowering $\mathrm{CH}_{4}$ emissions (Beauchemin et al., 2008). Refined oils, such as coconut oil, contain high concentrations of medium-chain fatty acids (MCFA), particularly lauric and myristic fatty acids (Machmüller et al., 2001). Reductions in $\mathrm{CH}_{4}$ yield attributed to coconut oil are reported to be mediated by these MCFA (Dohme et al., 2001) as they have antimicrobial properties and are toxic to methanogens. Reductions in both protozoa and methanogen numbers in response to MCFA have been reported by Machmüller (2006).

g. Methane oxidizers. An experiment demonstrated that methane oxidizing bacteria from gut of young pigs decrease methane accumulation when added to rumen fluid in vitro. However, this approach has not been validated in vivo (Shete and Tomar, 2010).

h. Immunization with methanogen vaccine. In a study conducted in Australia with the vaccination of sheep with a number of experimental vaccine preparations against methanogens, it showed that sheep were able to produce antibodies against methanogens (Shete and Tomar, 2010). Methane production was reduced by $11 \%$ to $23 \%$ in vaccinated animals and productivity was also improved. Some new approaches like use of bacteriocins, bacteriophages, herbal products, genetic manipulation of methanogens, etc. were tried by researchers (McAllister and Newbold, 2008).

\section{CONCLUSION}

Climate change exhibit impacts on the profitability and performance of livestock by lowering feed intake, nutrient utilization, growth rate, reproduction, and disease resistance. Several strategies for adaptation to the effect of climate change and mitigation options to lessen GHG emissions are available for application. Thus, knowledge with effective utilization of these strategies may reduce the negative impacts of the changing climate on livestock production system for sustainable and productive animal farming. 
Climate Change Impacts on Livestock Production Systems

\section{REFERENCES}

ADAMS, R.M., B.H. HURD, S. LENHART AND N. LEARY. 1998. Effects of global climate change on agriculture: an interpretative review. Clim. Res. 11:19-30.

AJISAKA, N., N. MOHAMMED, K. HARA, K. MIKUNI, K. HARA, H. HASHIMOTO, T. KUMATA, S. KANDA AND H. ITABASHI. 2002. Effects of medium-chain fatty acid-cyclodextrin complexes on ruminal methane production in vitro. Animal Science Journal 73: 479-484.

AMON, B., V. KRYVORUCHKO, T. AMON AND S. ZECHMEISTERBOLTENSTERN. 2006. Methane, nitrous oxide and ammonia emissions during storage and after application of dairy cattle slurry and influence of slurry treatment. Agric. Ecosystem \& Environ. 112: 153-162.

ARMSTRONG, D. AND F. WIERSMA. 1986. An update on cow cooling methods in the west. ASAE Paper 86-4034. ASAE, St. Joseph, MI, USA.

AYDINALP, C. AND M.S. CRESSER. 2008. The Effects of Global Climate Change on Agriculture. IDOSI Publications. American-Eurasian J. Agric. \& Environ. Sci. 3(5): 672-676.

BABINSZKY L., V. HALAS AND M.W.A. VERSTEGEN. 2011. Impacts of Climate Change on Animal Production and Quality of Animal Food Products, Climate Change-Socioeconomic Effects, Dr. Houshan Kheradmand (Ed.), I S B N : 978-953-307-411-5, In Tech, Available from:http://www.intechopen.com/books/climate-changesocioeconomic-effects/impacts-of-climate-change-onanimalproduction-and-quality-of-animal-food-products.

BASU, A.K. AND P.K. BANDHYOPADHYAY. 2004. The effect of season on the incidence of ticks. Bull. Anim. Health Prod. Afr. 52(1): 39-42.

BATIMA, P. 2007. Climate change vulnerability and adaptation in the livestock sector of Mongolia. Assessments of impacts and adaptations to climate change. International START Secretariat, Washington DC, US. 
BAYLIS, M. AND A.K. GITHEKO. 2006. The effects of climate change on infectious diseases of animals. Report for the Foresight Project on Detection of Infectious Diseases, Department of Trade and Industry, UK Government.

BEAUCHEMIN, K.A. AND S.M. MCGINN. 2008. Reducing Methane in Dairy and Beef Cattle Operations: What is Feasible? pp. 17-21.

BEAUCHEMIN, K.A., M. KREUZER, F. O'MARA AND T.A. MCALLISTER. 2008. Nutritional management for enteric methane abatement: a review. Austr J Exp Agric 48(1-2): 21-27.

BENCHAAR, C., C. POMAR AND J. CHIQUETTE. 2001. Evaluation of dietary strategies to reduce methane production in ruminants: a modelling approach.Can. J. Anim. Sci. 81: 563-574.

BERG, W., R. BRUNSCH AND I. PAZSICZKI. 2006. Greenhouse gas emissions from covered slurry compared with uncovered during storage. Agriculture, Ecosystems \& Environment 112: 129-134.

BROWN-BRANDL, T.M., R.A. EIGENBERG, J.A. NIENABER AND S.D. KACHMAN. 2001. Thermoregulatory profile of a newer genetic line of pigs. Livestock Production Science 71: 2-3.

BUCKLIN, R.A., L.W. TURNER, D.K. BEEDE, D.R. BRAY AND R.W. HEMKEN. 1991. Methods to relieve heat stress for dairy cows in hot, humid climates. Appl. Eng. Agric. 7: 241-247.

BUFFINGTON, D.E., R.J. COLLIER AND G.H. CANTON. 1983. Shade management systems to reduce heat stress for dairy cows. Trans. ASAE 26: $1798-1802$.

CALSAMIGLIA, S., M. BUSQUET, P.W. CARDOZO, L. CASTILLEJOS AND A. FERRET. 2007. Invited review: Essential oils as modifiers of rumen microbial fermentation. J. Dairy Sci. 90: 2580-2595.

CAPILI, E.B., A.C.S. IBAY AND J.R.T. VILLARIN. 2005. Climate Change Impacts and Adaptation on Philippine Coasts. Proceedings of the International Oceans 2005 Conference.19-23 September 2005, Washington D.C., USA. 
Climate Change Impacts on Livestock Production Systems

CHAVES, A.V., L.C. THOMPSON, A.D. IWAASA, S.L. SCOTT, M.E. OLSON, C. BENCHAAR, D.M. VEIRA AND T.A. MCALLISTER. 2006. Effect of pasture type (alfalfa vs grass) on methane and carbon dioxide production by yearling beef heifers. Can. J. Anim. Sci. 86: 409-418.

CICEK, N., X. ZHOU, Q. ZHANG AND M. TENUTA. 2004. Impact of straw cover on greenhouse gas and odor emissions from manure storage lagoons using a flux hood. Paper No. 044054, ASAE Annual International Meeting, Ottawa, Ontario, Canada, 1-4 August 2004, ASAE.

CLOSE, W.H. 1989. The influence of thermal environment on the voluntary food intake of pigs. In: The voluntary food intake of pigs, J.M. Forbes, M.A. Varley, T.L.J. Lawrence, (Eds), British Society of Animal Production, Edinburgh.

COLLIN, A., J. VAN MILGEN, S. DUBOIS AND J. NOBLET. 2001. Effect of high temperature on feeding behavior and heat production in group-housed young pigs. British Journal of Nutrition 86: 63-70.

COMMISSION ON GENETIC RESOURCES FOR FOOD AND AGRICULTURE (CGRFA). 2007. The State of the World's Animal Genetic Resources for Food and Agriculture. FAO, Rome.

CZERKAWSKI, J. W., K.L. BLAXTER AND F.W. WAINMAN. 1966. The effect of linseed oil and of linseed oil fatty acids incorporated in the diet on the metabolism of sheep. Br. J. Nutr. 20: 485-494.

DEL GROSSO, S.J., J. DUFFIELD, M.D. EVE, L. HEATH, S. OGLE, J. SMITH AND T. WIRTH. 2011. U.S. Agriculture and Forestry Greenhouse Gas Inventory: 1990- 2008. Climate Change Program Office, Office of the Chief Economist, U.S. Department of Agriculture. Technical Bulletin No. 1930.

DEL GROSSO, S.J., S. OGLE, J. WIRTH AND S. SKILES. 2008. U.S. Agriculture and Forestry Greenhouse Gas Inventory: 1990-2005. United States Department of Agriculture Technical Bulletin 1921.

DOHME, F., A. MACHMÜLLER, A. WASSERFALLEN AND M. KREUZER. 2001. Ruminal methanogenesis as influenced by individual fatty acids supplemented to complete ruminant diets. Letters in Applied Microbiology 32: 47-51. 
Poliquit

DOURMAD, J., C. RIGOLO AND H. VAN DER WERF. 2008. Emission of Greenhouse Gas: Developing management and animal farming systems to assist mitigation. Livestock and Global Change conference proceeding. May 2008, Tunisia.

DUNKLEY, C. S. AND K. D. DUNKLEY. 2013. Greenhouse Gas Emissions from Livestock and Poultry. Agric. Food Anal. Bacteriol.3(1):17-29.

EUGENE, M., D. MASSE, J. CHIQUETTE AND C. BENCHAAR. 2008. Short communication: Meta-analysis on the effects of lipid supplementation on methane production in lactating dairy cows. Can. J. Anim. Sci. 88: 331-334.

ENVIRONMENTAL PROTECTION AGENCY (EPA). 2011. Inventory of U.S. Greenhouse Gas Emissions and Sinks: 1990-2009. U.S.A.

FOOD AND AGRICULTURE ORGANIZATION (FAO). 2008a. The state of world fisheries and aquaculture. Rome, Italy.

FOOD AND AGRICULTURE ORGANIZATION (FAO). 2008b. Climaterelated Transboundary Pests and Diseases Including Relevant Aquatic Species. Rome, Italy.

FOOD AND AGRICULTURE ORGANIZATION (FAO). 2007. Adaptation to Climate Change in Agriculture, Forestry, and Fisheries: perspective, framework and priorities. Rome, Italy.

FRÉDÉRIC, P., G. STÉPHANE, P.L. STÉPHANE, D.V.B. ROBERT, P. SYLVAIN AND D. JEAN-YVES. 2007. Valuation of Greenhouse Gas Emissions from Five Swine Production Systems Based on Life Cycle Assessment. Paper presented at the 2007 ASAE Annual Meeting. Retrieved from http://asae.frymulti.com/abstract.asp?adid $=23065 \& \mathrm{t}=5$.

GARCIA-GONZALEZ, R., S. LOPEZ, M. FERNANDEZ, R. BODAS AND J.S. GONZALEZ. 2008. Screening the activity of plants and spices for decreasing ruminal methane production in vitro. Anim. Feed Sci. Technol. 147:36-52.

GIBBS, M.J. AND R.A. LENG. 1993. Methane Emissions From Livestock: Methane And Nitrous Oxide, Proceedings of the International IPCC Workshop, Amersfoort, The Netherlands. 
Climate Change Impacts on Livestock Production Systems

GROFFMAN, P.M., R. BRUMME, K. BUTTERBACH-BAHL, K.E. DOBBIE, A.R. MOSIER, D. OJIMA, H. PAPEN, W.J. PARTON, K.A. SMITH AND C. WAGNER-RIDDLE. 2000. Evaluating annual nitrous oxide fluxes at the ecosystem scale. Global Biogeochemcial Cycles, 14(4): 1061-1070

GUAN, H., K.M. WITTENBERG, K.H. OMINSKI AND D.O. KRAUSE. 2006. Efficacy of ionophores in cattle diets for mitigation of enteric methane. J. Anim Sci. 84: 1896-1906.

HAHN, G.L. 1989. Bioclimatology and livestock housing: theoretical and applied aspects. Proc. Brazilian Workshop on Animal Bioclimatology. Jaboticabal, Brazil.

HAHN, G.L. 1985. Management and housing of farm animals in hot environments. In: Yousef, M.K (ed.) Stress physiology in Livestock, Volume II, Ungulates. CRC Press, Boca Raton, FL, USA.

HARPER, L.A., R.R. SHARPE AND T.B. PARKIN. 2000. Gaseous nitrogen emissions from anaerobic swine lagoons: ammonia, nitrous oxide, and dinitrogen gas. J. Environ. Qual. 29: 1356-1365.

HARVELL, C.D., C.E. MITCHELL, J.R. WARD, S. ALTIZER, A.P. DOBSON, R.S. OSTFELD AND M.D. SAMUEL. 2002. Ecology - climate warming and disease risks for terrestrial and marine biota. Science 296: 2158-2162.

HEGARTY, R. 2001. Greenhouse gas emissions from the Australian livestock sector. Australian Greenhouse Office.

HELLER, E.D., D.B. NATHAN AND M. PEREK. 1979. Short heat stress as an immune stimulant in chicks. Avian Pathology 8:195-203

HERRERO, M., P. GERBER, T. VELLINGA, T. GARNETT, A. LEIP, C. OPIO, H.J. WESTHOEK, P.K. THORNTON, J. OLESEN, N. HUTCHINGS, H. MONTGOMERY, J.F. SOUSSANA, H. STEINFELD AND T.A. MCALLISTER. 2011. Livestock and greenhouse gas emissions: The importance of getting the numbers right, Animal Feed Science and Technology, 166-167: 779-782. 
HOFFMANN, I. 2008. Livestock Genetic Diversity and Climate Change Adaptation. Livestock and Global Change conference proceeding. Tunisia.

HOPKINS, A. AND A. DEL PRADO. 2007. Implications of climate change for grassland in Europe: impacts, adaptations and mitigation options: a review. Grass and Forage Science 62:118-126.

HOUNGHTON, J.T., Y. DING, D.J. GRIGGS, M. NOGUER, P.J. VAN DER LINDEN, X. DAI, K. MASKELL AND C.A. JOHNSON. 2001. Climate change: The scientific basis. Contribution of working group I to the third assessment report of the Intergovernmental Panel on Climate Change. New York: Cambridge University Press.

HUSTED, S. 1994. Seasonal variation in methane emission from stirred slurry and solid manures. J. Environ. Qual. 23: 585-592.

HUYNH, T.T.T., A.J.A. AARNINK, M.W.A. VERSTEGEN, W.J.J. GERRITS, M.J.W. HEETKAMP, B. KEMP AND T.T. CANH. 2005. Effects of increasing temperatures on physiological changes in pigs at different relative humidities. American Society of Animal Science. J ANIM SCI 83:13851396.

INTERGOVERNMENTAL PANEL ON CLIMATE CHANGE (IPCC). 2007. Working group III. Climate change 2007: mitigation of climate change. Accessed online on 0ct 22, 2012 at http://www.ipcc.ch/ publications_and_data/publications_ipcc_fourth_assessment report_wg3_report_mitigation_of_climate_change.htm

INTERNATIONAL FUND FOR AGRICULTURAL DEVELOPMENT (IFAD). 2009. Livestock and Climate Change. Rome, Italy.

IPHARRAGUERRE, I.R., AND J.H. CLARK. 2003. Usefulness of ionophores for lactating dairy cows: a review. Animal Feed Science and Technology 106: 39-57.

JANZEN, H.H. 2011. What place for livestock on a re-greening earth? Animal Feed Science and Technology, 166-167: 783-796. 
Climate Change Impacts on Livestock Production Systems

JOBLIN, K.N. 1999. Ruminal acetogens and their potential to lower ruminant methane emissions. Aust. J. Agric. Res. 50:1307-1314.

JORDAN, E., D.K. LOVETT, F.J. MONAHAN, J. CALLAN, B. FLYNN AND F.P. O'MARA. 2006. Effect of refined coconut oil or copra meal on methane output and on intake and performance of beef heifers. J Anim Sci. 84: 162-170.

KERR, B.J., J.T. YEN, J.A. NIENABER AND R.A. EASTER. 2003. Influences of dietary protein level, amino acid supplementation and environmental temperature on performance, body composition, organ weights and total heat production of growing pigs, Journal of Animal Science, 81: 1998-2007.

KOVATS, R.S., D.H. CAMPBELL-LENDRUM, A.J. MCMICHAEL, A. WOODWARD, J. COX AND H. ST. 2001. Early effects of climate change: do they include changes in vector-borne disease? Philosophical Transactions of the Royal Society, London, Series B 356: 1058-1068.

LACETERA, N., U. BERNABUCCI, D. SCALIA, A. NARDONE AND B. RONCHI. 2002. Moderate summer heat stress does not modify immunological parameters of Holstein dairy cows. International Journal of Biometeorology, 46(1): 33-37.

LE BELLEGO, L., J. VAN MILGEN AND J. NOBLET. 2002. Effect of high ambient temperature on protein and lipid deposition and energy utilization in growing pigs. Animal Sci., 75: 85-96.

LESSCHEN, J.P., M. VAN DER BERG, H.J. WESTHOEK, H.P. WITZKE AND O. OENEMA. 2011. Greenhouse gas emission profiles of European livestock sectors. Anim. Feed Sci. and Tech. 166-167: 16-28.

LOPEZ-REAL, J.M. AND M. BAPTISTA. 1996. Preliminary comparative study of three manure composting systems and their influence on process parameters and methane emissions. Compost Science \& Utilization, 4(3): 71-82.

LOVETT, J.C., G.F. MIDGELY AND P.B. BARNARD. 2005. Climate change and ecology in Africa. African Journal of Ecology 43: 279-281. 
MACHMULLER, A. 2006. Medium-chain fatty acids and their potential to reduce methanogenesis in domestic ruminants. Agric. Ecosyst. Environ.112:107-114.

MACHMULLER, A., C.R. SOLIVA AND M. KREUZER. 2003. Methanesuppressing effect of myristic acid in sheep as affected by dietary calcium and forage proportion. Br. J. Nutr. 90: 529-540.

MACHMÜLLER, A., F. DOHME, C.R. SOLIVA, M. WANNER AND M. KREUZER. 2001. Diet composition affects the level of ruminal methane suppression by medium-chain fatty acids. Australian Journal of Agricultural Research 52:713-722.

MANDAL, D.K., A.V.M.S. RAO, K. SINGH AND S.P. SINGH. 2002. Effects of macroclimatic factors on milk production in a Frieswal herd. Indian J Dairy Sci. 55(3):166-170.

MARTIN, C., D.P. MORGAVI, AND M. DOREAU. 2010. Methane mitigation in ruminants: From microbe to the farm scale. Animal 4:351-365.

MARTIN, C., J. ROUEL, J.P. JOUANY, M. DOREAU AND Y. CHILLIARD. 2008. Methane output and diet digestibility in response to feeding dairy cow's crude linseed, extruded linseed, or linseed oil. J Anim Sci. 86: 2642-2650.

MAURYA, R.K. 2010. Alternate dairy management practices in draught prone areas of Bundelkhand region of Uttar Pradesh, M.V.Sc. Thesis, Deemed University Indian Veterinary Research Institute, Izatnagar, India.

MCALLISTER, T.A. AND C.J. NEWBOLD. 2008. Redirecting rumen fermentation to reduce methanogenesis. Austr. J. Exp. Agric. 48: 7-13.

MCCAUGHEY, W.P., K. WITTENBERG AND D. CORRIGAN. 1999. Impact of pasture type on methane production by lactating beef cows. Can. J. Anim. Sci. 79: 221-226.

MCGUFFEY, R.K., L.F. RICHARDSON AND J.I.D. WILKINSON. 2001. Ionophores for dairy cattle: Current status and future outlook. Journal of Dairy Sci. 84: 194-203. 
Climate Change Impacts on Livestock Production Systems

MCMICHAEL, A.J., J.W. POWLES, C.D. BUTLER AND R. UAUY. 2007. Food, livestock production, energy, climate change, and health. Lancet 370: 1253-1263.

MESSIAS DE BRAGAN CA, M., A.M. MOUNIER AND A. PRUNIER. 1998. Does feed restriction mimic the effects of increased ambient temperature in lactating sow? Journal of Animal Science, 76: 2017-2024.

MONTENY, G.J., A. BANNINK AND D. CHADWICK. 2006. Greenhouse gas abatement strategies for animal husbandry. Agriculture, Ecosystems \& Environment 112:163-170.

MYERS, R. AND R. BUCKLIN. 2001. Influence of Hot-Humid Environment on Growth Performance and Reproduction in Swine. University of Florida Extension. Institute of Food and Agricultural Sciences.

NATIONAL RESEARCH COUNCIL (NRC). 1981. Effect of Environment on Nutrient Requirements of Domestic Animals. Subcommittee on Environmental Stress, National Research Council. National Academy Press, Washington, DC.

O'MARA, F.P. 2011.The significance of livestock as a contributor to global greenhouse gas emissions today and in the near future. Animal Feed Sci. and Tech., 166-167: 7-15.

ODONGO, N.E., R. BAGG, G. VESSIE, P. DICK, M.M. OR-RASHID, S.E. HOOK, J.T. GRAY, E. KEBREAB, J. FRANCE AND B.W. MCBRIDE. 2007. Long-term effects of feeding monensin on methane production in lactating dairy cows. J. Dairy Sci. 90: 1781-1788.

PALMER, J.R. AND J.N. REEVE. 1993. In: Genetics and Molecular Biology of Anaerobic Bacteria Ed. Sebald, M., Springer-Verlag, New York, Berlin, Heidelberg, London, Paris, Tokyo, Hong Kong, Barcelona, Budapest.

PATIENCE, J.F. 1990. A review of the role of acid-base balance in amino acid nutrition, Journal of Animal Science, 68: 398-408.

PATZ, J.A., D. CAMPBELL-LENDRUM, T. HOLLOWAY AND J.A. FOLEY. 2005 a. Impact of regional climate change on human health. Nature 438: 310-317. 
PATZ, J.A., U.E.C. CONFALONIERI, F.P. AMERASINGHE, K.B. CHUA, P. DASZAK, A.D. HYATT, D. MOLYNEUX, M. THOMSON, L. YAMEOGO, M.M. LAZARO, P. VASCONCELOS, Y. RUBIO- PALIS, D. CAMPBELL-LENDRUM, T. JAENISCH, H. MAHAMAT, C. MUTERO, D. WALTNER-TOEWS AND C. WHITEMAN. 2005b. Human health: ecosystem regulation of infectious diseases. In: Ecosystems and Human Well-Being. Current State and Trends, vol. 1.The Millennium Ecosystem Assessment. http:// www. millenniumassessment.org (Chapter 14).

PETERSEN, S.O., B. AMON AND A. GATTINGER. 2005. Methane oxidation in slurry storage surface crusts. Journal of Environmental Quality, 34: 455-461.

PHILIPPINE COUNCIL FOR AGRICULTURE, FORESTRY AND NATURAL RESOURCES RESEARCH AND DEVELOPMENT (PCARRD). 2009. Philippine S\&T Agenda on Climate Change: Agriculture, Forestry and Natural Resources Sectors 2010-2016. Los Baños, Laguna. PCARRDDOST.

PRUNIER, A.M., M. MESSIAS DE BRAGAN AND J. LE DEVIDICH. 1997. Influence of high ambient temperature on performance of reproductive sows, Livestock Production Science, 52(2): 123-133.

QUINIOU, N., S. DUBOIS AND J. NOBLET. 2000. Voluntary feed intake and feeding behaviour of group-housed growing pigs are affected by ambient temperature and body weight. Livestock Production Science, 63(3): 245-253.

REAY, D.S., E.A. DAVIDSON, K.A. SMITH, P. SMITH, J.M. MELILLO, F. DENTENER AND P.J. CRUTZEN. 2012. Global agriculture and nitrous oxide emissions. Nature Climate Change Vol. 2.

RENAUDEAU, D., A. COLLIN, S. YAHAV, V. DE BASILIO, J. GOURDINE AND R.J. COLLIER. 2010. Adaptation to tropical climate and research strategies to alleviate heat stress in livestock production. Advances in Animal Biosciences, 1(2): 378-379.

RÖTTER, R. AND S.C. VAN DE GEIJN. 1999. Climate change effects on plant growth, crop yield and livestock. Climatic Change 43: 651-681. 
Climate Change Impacts on Livestock Production Systems

ROWLINSON, P. 2008. Adapting Livestock Production Systems to Climate Change - Temperate Zones. Livestock and Global Change conference proceeding. May 2008, Tunisia.

RUIZ, R., G.L. ALBRECHT, L.O. TEDESCHI, G. JARVIS, J.B. RUSSELL AND D.G. FOX. 2001. Effect of monensin on the performance and nitrogen utilization of lactating dairy cows consuming fresh forage. Journal of Dairy Science 84: 1717-1727.

SCHULTZ, T.A. 1988. California dairy corral manger mister installation. ASAE Paper 88-4056, ASAE, St. Joseph, MI, USA.

SERÉ, C., A. VAN DER ZIJPP, G. PERSLEY AND E. REGE. 2008. Dynamics of livestock production systems, drivers of change and prospects for animal genetic resources. Animal Genetic Resources Information 42: 3-27.

SETSHWAELO, L.L. 2001. A Study of Grasslands/Livestock Vulnerability and Adaptation to Climate Change. Botswana.

SHETE, S.M. AND S.K. TOMAR. 2010. Ruminating over methane emissions. Science reporter.

SIDAHMED, A. 2008. Livestock and Climate Change: Coping and Risk Management Strategies for a Sustainable Future. In Livestock and Global Climate Change conference proceeding, May 2008, Tunisia.

STANDING COMMITTEE ON AGRICULTURE (SCA). 1990. Feeding Standards for Australian Livestock: Ruminants. CSIRO Publications, East Melbourne, Australia.

STATE OF FOOD AND AGRICULTURE (SFA). 2009. Livestock in the Balance.

STEINFELD, H., P. GERBER, T. WASSENAAR, V. CASTEL, M. ROSALES AND C. DE HAAN. 2006. Livestock's long shadow: Environmental issues and options. Food and Agriculture Organization of the United Nations (FAO), Rome, Italy. 
STEVENS, C.E. AND J.D. HUME. 1998. Contribution of microbes in vertebrate gastrointestinal tract to production and conservation of nutrients. Physiol. Rev. 78: 393-427.

STRICKLAND, J.T., R.A. BUCKLIN, R.A. NORSTEDT, D.K. BEEDE AND D.R. BRAY. 1989. Sprinkler and fan cooling system for dairy cows in hot, humid climates. Appl. Eng. Agric. 5: 231-236.

TAILOR, S.P. AND R.K. NAGDA. 2005. Conception rate in buffaloes maintained under sub humid climate of Rajasthan. Ind J Dairy Sci 58(1): 69-70.

THORNTON, P.K., J. VAN DE STEEG, A. NOTENBAERT AND M. HERRERO. 2009. The impacts of climate change on livestock and livestock systems in developing countries: A review of what we know and what we need to know. International Livestock Research Institute (ILRI), P.O. Box 30709, Nairobi, Kenya. Elsevier Ltd. Agricultural Systems 101: 113-127.

THORNTON, P., M. HERRERO, A. FREEMAN, O. MWAI, E. REGE, P. JONES AND J. MCDERMOTT. 2008. Vulnerability, Climate Change and LivestockResearch Opportunities and Challenges for Poverty Alleviation. ILRI, Kenya.

TUMMURUK, P., W. TANTASUPARUK, M. TECHAKUMPHU AND A. KUNAVONGKRIT. 2002. Seasonal effects on the reproductive performance of gilts and sows. Thai J Vet Med 32(3).

TURNER, L.W., J.P. CHASTAIN, R.W. HEMKEN, R.S. GATES AND W.L. CRIST. 1989. Reducing heat stress in dairy cows through sprinkler and fan cooling. ASAE Paper 89-4025. ASAE, St. Joseph, MI, USA.

UNITED NATIONS ENVIRONMENT PROGRAM GLOBAL ENVIRONMENTAL ALERT SERVICE (UNEP GEAS). 2012. Growing greenhouse gas emissions due to meat production. www.unep.org/geas.

UNITED NATIONS FRAMEWORK CONVENTION ON CLIMATE CHANGE (UNFCCC). 2008. Mechanisms to manage financial risks from direct impacts of climate change in developing countries. 
Climate Change Impacts on Livestock Production Systems

UNITED STATES AGRICULTURE AND FORESTRY GREENHOUSE GAS. 2008. Global Change Program Office, Office of the Chief Economist, U.S. Department of Agriculture. In Agric. Food Anal. Bacteriol. AFABjournal.com. Vol. 3, Issue 1 - 2013 29.Inventory: 1990-2005. Technical Bulletin No. 1921.

UPADHYAY, R.C, S.V. SINGH, A. KUMAR, S.K. GUPTA, AND A. ASHUTOSH. 2007. Impact of Climate change on Milk production of Murrah buffaloes. Italian Journal of Animal Science 6(2s): 1329-1332.

VALTORTA, S.E., M.R. GALLARDO, H.C. CASTRO AND M.C. CASTELLI. 1996. Artificial shade and supplementation effects on grazing dairy cows in Argentina. Trans. ASAE 39: 233-236.

VALTORTA S.E., P.E. LEVA AND M.R. GALLARDO. 1997. Effect of different shades on animal well-being in Argentina. Int. J. Biometeorol. 41: 6567.

VALTORTA, S.E., P.E. LEVA, M.R. GALLARDO AND O.E. SCARPATI. 2002. Milk production responses during heat waves events in Argentina. 15th Conference on Biometeorology and Aerobiology - 16th International Congress on Biometeorology. Kansas City, MO. American Meteorological Society, Boston.

VEGA, R.S.A., E.M. JR. AGBISIT, A.T. CALUB AND E.C. VILLAR. 2002. The third quarter reproductive syndrome as experienced by commercial farms. Animal Husbandry \& Agriculture Journal.

WETTEMANN, R.P., M.E. WELLS AND R.K. JOHNSON. 1979. Reproductive characteristics of boars during and after exposure to increased ambient temperature. Journal of Animal Science 49: 1501-1505.

WITTMANN, E.J. AND M. BAYLIS. 2000. Climate change: effects on Culicoides-transmitted viruses and implications for the UK. The Veterinary Journal 160: 107-117.

WORLD FOOD PROGRAMME (WFP). 2013. Disaster Preparedness and Response Programme: Building Resilience against Disasters and Climate Change. 2 pp. http://www.nature.com/naturejobs/2013 /130314/images/nj7440-271a-i2.0.jpg 
WORLD HEALTH ORGANIZATION (WHO). 1996. Climate Change and Human Health. World Health Organization, Geneva.

WORLD RESOURCES INSTITUTE (WRI). 2005. Navigating the numbers: Greenhouse Gas Data and International Climate Policy. Accessed online on Oct 22, 2012 at http://pdf.wri.org/navigating_numbers.pdf

WORLD SOCIETY FOR THE PROTECTION OF ANIMALS (WSPA). 2012. Livestock production and climate change.

ZIJDERVELD, S. 2011. Dietary strategies to reduce methane emissions from ruminants. Wageningen University.

ZULKIFI, I., M.T. NORMA, D.A. ISRAF, AND A.R. OMAR. 2000. The effect of early age feed restriction on subsequent response the high environmental temperature in female broiler chickens. Poultry Science, 79: 1401-1407. 